Vol. 1 No. 2, Hal 88-94, April 2020

\title{
Fabrikasi Lapisan Nano Fluorine Doped Tin Oxide (FTO) Dengan Variasi Temperature Menghasilakan Material Bersifat Transparan Dan Konduktif
}

\author{
Mirza Yusuf*, Suciatno \\ Program Studi Teknologi Mesin, Program Vokasi, Universitas Muhammadiyah Yogyakarta, \\ Jl. Brawijaya, Tamantirto, Kasihan, Bantul, Yogyakarta 55183 \\ *Email:mirza@umy.ac.id
}

Histori artikel: diserahkan 25 Maret 2020, direviu 26 Maret 2020, direvisi 29 Maret 2020

\begin{abstract}
The process of forming a doped Tin oxide (FTO) nano fluoride layer was made using Tin Chloride $\left(\mathrm{SNCL}_{2}\right)$ with Ammonium Fluoride $\left(\mathrm{NH}_{4} \mathrm{~F}\right)$ mixing process using a magnetic stirrer at room temperature $\left(28^{\circ} \mathrm{C}\right)$. The solvent liquid uses $99 \%$ ethanol. Both of these solutions are mixing and finally get the fluorinated doped fluorine Tin. The deposition method of the nanolayer uses the pyrolysis process to produce FTO substrates. This research focused on the production of materials that have transparent properties and have conductivity values. It based on the requirements of work solar cells to work. The process of measuring transparency uses an absorbance measurement tool. Measurement of conductivity using a conductivity meter with a 4-point circular Probe method used in this study was divided into four variations, including starting from 400, 425, 450, 475, 500 degrees Celsius. From this method, the best results were obtained at a temperature of 475 degrees Celsius with an average value of $25 \Omega / \mathrm{cm}$ and the highest percentage of transmittance.
\end{abstract}

Kata kunci: pyrolysis flouride doped Tin oxide, kaca, temperature, Four Point Probe.

DOI: $10.18196 /$ jqt.010213

Web: http://journal.umy.ac.id/index.php/qt

\section{PENDAHULUAN}

Menurut Arini dkk, 2017 dalam penelitiannya tentang pengaruh waktu deposisi dan temperatur subtrat terhadap pembuatan kaca konduktif FTO. Metode yang digunakan kombinasi metode sol-gel untuk preparasi larutan kaca konduktif dan teknik untrasonic spray pyrolysis untuk deposisi film tipis FTO (fluoride doped tin oxide). Percobaan ini menggunakan bahan baku timah (II) klorida hidrat $\left(\mathrm{SnCl}_{2} \cdot 2 \mathrm{H}_{2} \mathrm{O}\right)$ dan $\mathrm{NH}_{4} \mathrm{~F}$ sebagai doping dengan rasio $6 \%$ dengan pemberian vasiasi temperatur $250^{\circ} \mathrm{C}, 300^{\circ} \mathrm{C}, 350^{\circ} \mathrm{C}, 400^{\circ} \mathrm{C}$ dan dengan variasi waktu deposisi 5, 20, 30, dan 40 menit.

Pada percobaan ini diperoleh kesimpulan semakin lama waktu deposisi akan mengakibatkan menambah ketebalan lapisan tipis FTO, sehingga akan berakibat semakin kecil nilai resistivitas kaca konduktif dan berpengaruh terhadap nilai transmitasinya yang semakin kecil. Peningkatan temperatur subtrat akan berpengaruh pada meningkatnya lapisan tipis FTO, sehingga tahanan listrik menurun dan terlalu tebal dapat menimbulkan efek buruk pada transparansi optik. Hasil optimal dalam percobaan ini adalah pada variasi waktu deposisi 5 menit dan temperatur subtrat $300^{\circ} \mathrm{C}$ didapatkan nilai resistivitas $3,16 \times 10^{-4} \Omega . \mathrm{cm}$ dan nilai transmitansinya $86,74 \%$.

Menurut Widiyandari dkk, 2012 dalam penelitiannya tentang fabrikasi kaca FTO, penelitian ini menggunakan metode deposisi spray. Bahan yang digunakan $\mathrm{SnCl}_{2} \cdot 2 \mathrm{H}_{2} \mathrm{O}$ dengan kosentrasi $0,7 \mathrm{M}$, kandungan doping $\mathrm{NH}_{4} \mathrm{~F} 6 \%$ dan etanol 96\%. Selanjutnya larutan yang telah dibuat diatomisasi dan dideposisi diatas permukaan kaca. Temperatur yang digunakan dalam fabrikasi kaca yaitu $500^{\circ} \mathrm{C}$. 
Hasil penelitian ini diperoleh nilai transmitasi $80 \%$ dan didapatkan sheet resistance $12 \Omega . \mathrm{cm}$

\section{Sel Surya}

Sel surya merupakan devais yang digunakan untuk mengkonversi energi matahari menjadi energi listrik. Salah satu contoh teknologi pemanfaatan energi matahari yang sedang dikembangkan saat ini yaitu sel surya berbasis dye/pewarna DSSC (Dye-Sensitized Solar Cell) (Noor et al., 2015). DSSC pertama kali ditemukan oleh seorang professor yang bernama Gratzel pada tahun 1991. Untuk fabrikasi sel surya jenis ini diperlukan beberapa komponen meliputi gelas transparan konduktif, semikonduktor, pewarna, elektrolit dan katalis counter electrode. Sampai saat ini material yang banyak digunakan sebagai gelas transparan konduktif adalah FTO, karena pada umumya lebih resistan secara kimiawi, murah dan ketersediaan bahan baku yang mudah diperoleh.

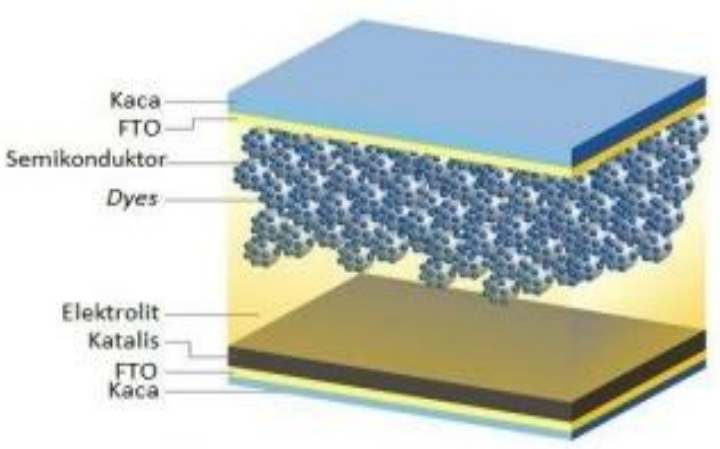

GAMBAR 1. Lapisan sandwich DSSC

(Hao et al., 2011)

\section{Kaca FTO}

Kaca FTO (Fluorine-doped Tin Oxide) termasuk salah material TCO (Transparent Conductive Oxide) yang banyak digunakan sebagai kaca konduktif transparan. Kaca FTO terbuat dari bahan dasar material yang permukaannya kacanya dideposisi dengan larutan prekusor yaitu lautan $\mathrm{SnCl}_{2} \cdot 2 \mathrm{H}_{2} \mathrm{O}$ dan $\mathrm{NH}_{4} \mathrm{~F}$ yang dilarutkan dalam etanol $96 \%$. Sifat optik yang dimiliki oleh kaca FTO jika ditinjau dari sifat listiknya merupakan material semikonduktor (resistivitas 104-109 $\Omega . c m$ ) dengan konduktivitas listrik yang berada diantara isolator (resistivitas $1014-1022$ $\Omega . \mathrm{cm}$ ) dan konduktor (resistivitas 10-5 $\Omega . \mathrm{cm}$ )
(Setiawan et al., 2007) Selain itu sifat optik yang lainnya dapat diketahui dari bagaimana interaksi kaca FTO dengan cahaya, hasil dari interaksi tersebut akan didapatkan seberapa besar transmitansi yang dimiliki oleh kaca FTO. Pada umumnya kaca FTO memiliki tingkat transparansi antara $68-85 \%$ pada panjang gelombang antara 400-800 $\mathrm{nm}$, besar kecilnya tingkat transparansi akan mempengaruhi kemampuan kaca FTO dalam penyerapan cahaya matahari. Kelebihan dari kaca jenis ini adalah sifat konduktivitas listrik yang relatif lebih tahan terhadap perlakuan pemanasan, lebih resisten terhadap kimiawi, harganya yang relatif murah dan ketersediaan bahan baku yang mudah diperoleh. Sehingga kaca FTO dapat digunakan sebagai pelapis substrat semikonduktor pada perangkat DSSC (Widiyandari et al., 2012).

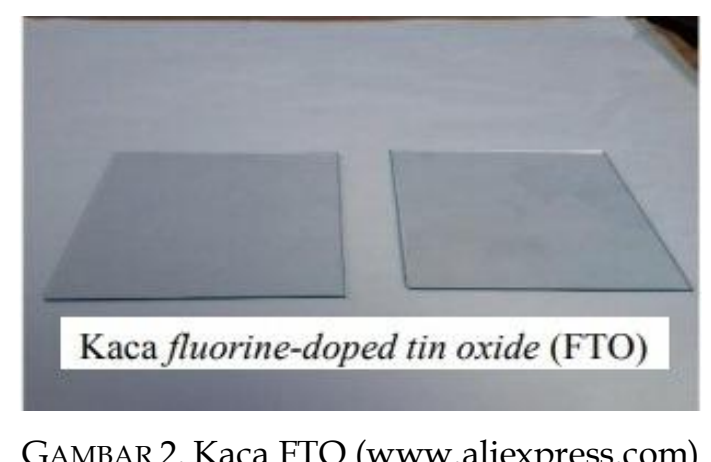

Proses Fabrikasi

\section{Elemen-Elemen Kaca FTO}

Bahan-bahan yang dijadikan sebagai elemen dalam pembuatan kaca FTO dapat dideskripsikan sebagai berikut : 1. Substrat Kaca Substrat kaca merupakan sebuah tempat melekatnya bagian-bagian dari elemen DSSC. Dipilih karena kemampuan substrat kaca yang mampu bertransparansi terhadap cahaya meskipun telah terlapisi oleh zat semikonduktor (Fauziah \& Fitri, 2013).

\section{$\mathrm{SnCl} 2.2 \mathrm{H} 2 \mathrm{O}$}

$\mathrm{SnCl}_{2}$ Merupakan $\mathrm{Sn}$ adalah timah dan $\mathrm{Cl}$ adalah klorida. Timah (II) klorida adalah bahan kimia berbentuk kristal berwarna putih dan terikat dengan molekul air yaitu $2 \mathrm{H}_{2} \mathrm{O}$. Timah (II) klorida hidrat digunakan untuk membuat 
gelas FTO (Widiyandari dkk, 2012) dengan konsentrasi 0,7 M serta memerlukan oksigen sebagai pereaksinya. Sifat yang dimiliki oleh $\mathrm{SnCl}_{2}$ yaitu memiliki desnsity $2,71 \mathrm{~g} / \mathrm{cm}^{3}$, melting point $37,7^{\circ} \mathrm{C}$ dan boiling point $623^{\circ} \mathrm{C}$

\section{$\mathrm{NH}_{4} \mathrm{~F}$}

Ammonium fluoride adalah bahan kimia berbentuk kristal berwarna putih. $\mathrm{NH}_{4} \mathrm{~F}$ digunakan sebagai doping dalam fabrikasi kaca FTO, doping berfungi untuk menaikan sifat dari $\mathrm{SnO}_{2}$ dengan cara menyumbang gugus $\mathrm{F}$ pada $\mathrm{SnO}_{2}$. (Yadav, 2009). Sifat yang dimiliki dari $\mathrm{NH}_{4}$ adalah memiliki density $1,009 \mathrm{~g} / \mathrm{cm}^{3}$ dan melting point $100^{\circ} \mathrm{C}$.

\section{Etanol}

Etanol merupakan larutan yang bersifat inert (tidak bereaksi dengan komponen lain) dan sering dijadikan sebagai pelarut (Fauziah dan Fitri, 2013). Boiling point yang dimiliki oleh etanol adalah $78,4^{\circ} \mathrm{C}$ (Purba, 2009).

\section{METODE PENELITIAN}

\section{Reaksi Kimia}

Reaksi kimia yang terjadi pada percampuran larutan $\mathrm{SnCl}_{2} .2 \mathrm{H}_{2} \mathrm{O}$, etanol $96 \%$ dan $\mathrm{NH}_{4} \mathrm{~F}$ adalah sebagai berikut :

a. Etanol $96 \%$ dijadikan sebagai pelarut

b. Pembentukan lapisan $\mathrm{SnO} 2$ dari pemisahan senyawa $\mathrm{SnCl}_{2} \cdot 2 \mathrm{H}_{2} \mathrm{O}$, ditunjukkan pada persamaan 1 ,

$\mathrm{SnCl} 2+2 \mathrm{H}_{2} \mathrm{O} \rightarrow \mathrm{SnO}_{2}+4 \mathrm{HCl}$

c. Reaksi dekomposisi dari senyawa amonim fluoride ditunjukkan pada persamaan 2, $\mathrm{NH}_{4} \mathrm{~F} \rightarrow \mathrm{NH}_{3}+\mathrm{HF}$

d. Ketika proses deposisi berlangsung larutan $\mathrm{SnCl}_{2} \cdot 2 \mathrm{H}_{2} \mathrm{O}+\mathrm{NH}_{4} \mathrm{~F}$ akan mengalami ionisasi larutan sehingga menjadi $\mathrm{SnO} 2$.

\section{Sintering}

Sintering (pemanasan) adalah pemanasan dengan menggunakan temperatur dibawah titik leleh suatu material, tujuan dari sintering yaitu untuk merubah struktur porositas suatu material (Nayiroh, 2013). Pada pembuatan kaca FTO temperatur sintering digunakan untuk membuka pori-pori lapisan kaca, sehingga pada saat proses ionisasi larutan droplet dapat terdeposisi kedalam lapisan kaca. Hal-hal yang mempengaruhi sintering yaitu temperatur, waktu, kecepatan pemanasan, kecepatan pendinginan, atmosfer sintering dan jenis material. Sintering dilakukan menggunakan tungku listrik (heater) yang diprogram sesuai dengan kebutuhan temperatur yang akan digunakan.

\section{Metode Spray Pyrolysis Deposition}

Merupakan metode untuk menghasilkan partikel produk berukuran mikrometer, submikrometer ataupun nanometer tergantung kosentrasi prekusor, selanjutnya partikel digunakan untuk membuat lapisan tipis semikonduktor (Widiyastuti dkk, 2011). Proses dari Spray Pyrolysis Deposition yaitu larutan yang telah dibuat dimasukkan kedalam wadah ultrasonic nebulizer untuk menjadikan partikel berukuran nano, kemudian diatomisasi dan dideposisi atas permukaan gelas. Proses deposisi larutan menggunakan temperatur tinggi yaitu $500^{\circ} \mathrm{C}$ (Widiyandari dkk, 2012).

\section{Metode Sintering E Ionisasi larutan}

Metode ini merupakan metode yang sederhana dan dapat mengasilkan kaca FTO yang memiliki sifat optik yang tinggi. Prosesnya terlebih dahulu subtrat kaca dipanaskan dengan menggunakan tungku listrik (heater), lalu kaca di sintering dengan temperatur tertentu agar pori-pori lapisan kaca terbuka, setelah itu pendeposisian larutan ke lapisan kaca yang terbuka pori-porinya dan kaca tersebut akan mengalami proses ionisasi larutan, proses ini akan terjadi perubahan pada muatan atom yang mengalami penambahan atau pengurangan elektron dari atom yang melebur. Jika atom tersebut saat melebur menangkap sejumlah elektron dari atom lain, maka atom akan bermuatan negatif dan apabila atom tersebut saat melebur melepaskan sejumlah elektron yang dimilikinya, maka atom tersebut bermuatan akan positif (Haryanto, 2015). 


\section{METODE PENGUJIAN}

Dalam penelitian ini ada 2 variabel yang akan diuji yaitu pengujian konduktifitas dan pengujian transmitansi. Dari kedua hal tersebut dihasilkan 1 buah gabungan variabel terbaik antara konduktiftas dan transmitansi.

\section{Pengujian Konduktifitas Four Point Probe}

Four Point Probe adalah alat yang digunakan untuk mengukur atau mengetahui nilai resistivitas $(\Omega-\mathrm{cm})$, tahanan atau resistansi $(\mathrm{R}, \Omega)$ dari suatu bahan elektronika yaitu bahan semikonduktor.

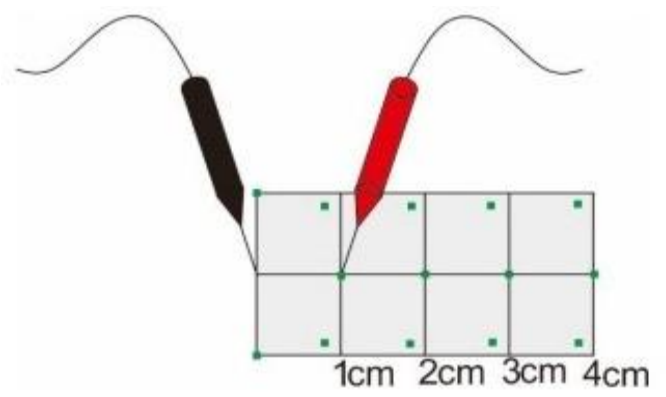

GAMBAR 3. Skema pengukuran Four Point Probe

Resistivitas merupakan merupakan salah satu parameter yang sangat penting dalam kelistrikan sel surya karena besar kecilnya resistivitas suatu bahan akan berpengaruh pada medan listrik yang dibutuhkan untuk menimbulkan sebuah kerapatan arus (Toifur \& Asmiarto, 2017). Dalam mekanisme kerja Four Point Probe yaitu dengan mengukur besarnya nilai $\mathrm{ohm} . \mathrm{cm}$ pada suatu material dalam radius per $1 \mathrm{~cm}$ dengan 4 titik melingkar, lalu hasil pengukuran ohm dilakukan rata-rata agar mendapatkan hasil yang lebih akurat dan persebaran merata dari tiap samplenya.

\section{Pengujian Transmitansi}

Spektrofotometer UV-Vis merupakan alat untuk mengukur transmitan atau absoban pada suatu material. Spektrofotometer sesuai merupakan alat yang terdiri dari spektrometer dan fonometer. Spektrometer digunakan untuk menghasilkan sinar dari spektrum dengan panjang gelombang (wave length) berkisar 200-900 nm dan fotometer adalah alat yang digunakan untuk mengukur intensitas cahaya yang dapat ditrasmisikan atau diabsorbsi.

Pengukuran kosentrasi larutan dengan menggunakan spektrofotometer UV-Vis untuk mengukur jumlah cahaya yang dapat diteruskan oleh suatu materal dengan panjang gelombang tertentu, besarnya cahaya yang dapat diteruskan oleh suatu material dapat digunakan untuk mengukur nilai transmitansi(Kurniawati, 2017). Pada fabrikasi kaca FTO pengujian ini bertujuan untuk mengetahui seberapa besar nilai transmitansi yang dimiliki oleh kaca FTO serta panjang gelombangnya $(\lambda)$, dengan cara menembakan sinar ultraviolet (UV) pada substrat kaca (Prasatya dan Diah, 2013).

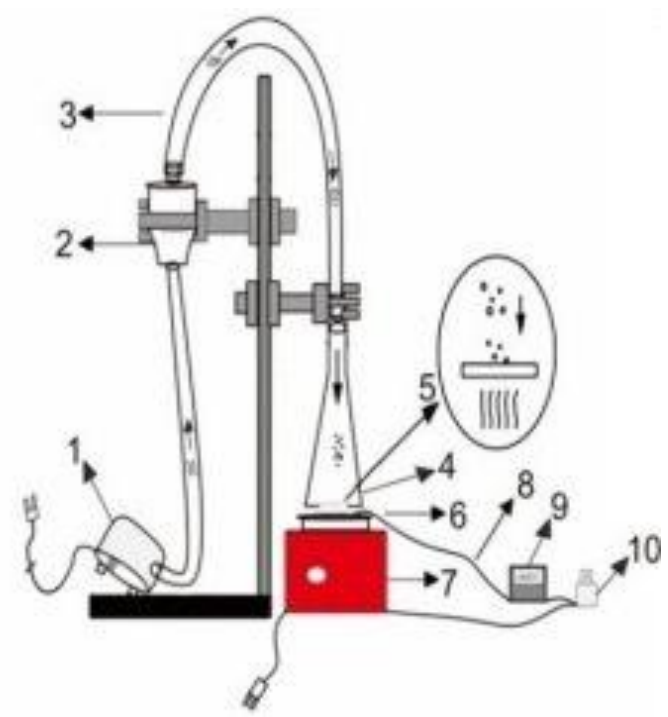

Keterangan:

1. Mesin ionisasi

2. Wadah larutan

3. Pipa

4. Cerobong

5. Kaca

6. Kolektor atau Plat besi

7. Heater

8. Thermokopel

9. Thermoreader

10. Relay

GAMBAR 4. Alat dan Komponen Fabrikasi FTO

Cara kerja dari alat fabrikasi kaca FTO yaitu mesin ionisasi berfungsi sebagai atomizer atau pengasil droplet dari larutan prekursor, droplet yang terbentuk kemudian akan dibawa oleh udara bebas bertekanan 2,5 bar dari wadah larutan menuju cerobong melalui saluran pipa. Selanjutnya kolektor dipanaskan dengan menggunakan heater sampai temperatur tertentu agar kaca yang terdapat di atas kolektor yang 
dapat terbuka pori-porinya, heater tersebut dilengkapi dengan termokopel dan relay yang berfungsi agar temperatur kolektor tetap terjaga di temperatur maksimalnya. Ketinggian cerobong pengionisasi diatur jaraknya agar ketika proses oksidasi mendapatkan suplai oksigen yang sesuai. Selanjutnya proses deposisi partikel terjadi di sepanjang cerobong sampai kolektor. Tahap terakhir yaitu pendinginan lambat sampai temperatur dibawah $50^{\circ} \mathrm{C}$ dengan cara mematikan alat fabrikasi kaca FTO dan mendiamkan posisi kaca ditempatnya.

\section{HASIL DAN PEMBAHASAN}

\section{Analisis Konduktivitas}

Pada kaca FTO untuk mengetahui besarnya nilai konduktivitas maka terlebih dahulu mengukur nilai resistivitasnya, semakin kecil nilai resistivitas yang dimiliki oleh kaca FTO akan semakin tinggi nilai konduktivitasnya. Pengukuran nilai resistivitas pada kaca FTO menggunakan metode four point probe radius per $1-4 \mathrm{~cm}$. Nilai resistivitas yang dihasilkan dipengaruhi oleh temperatur sintering seperti pada Gambar 5.

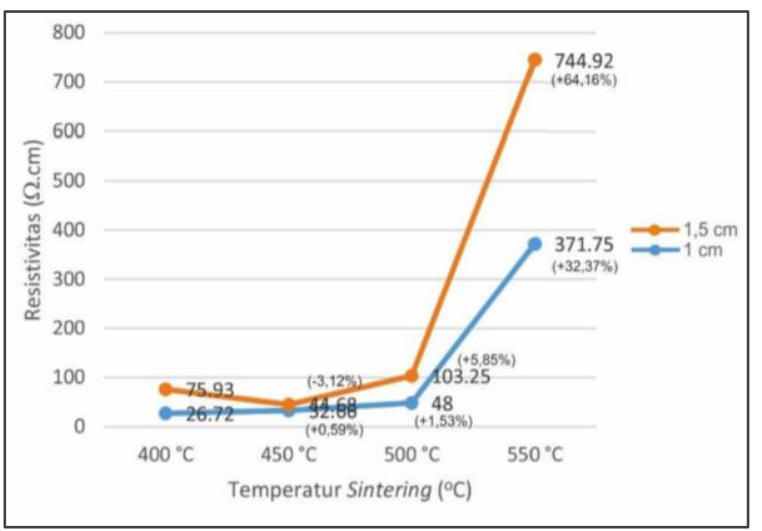

GAMBAR 5. Grafik hubungan resitivitas dengan temperatur sintering

Berdasarkan grafik tersebut, nilai resistivitas kaca FTO yang paling baik ditunjukan pada temperatur sintering $400^{\circ} \mathrm{C}$ yang memiliki nilai resistivitas $26,72 \Omega . \mathrm{cm}$, hasil nilai resistivitas sudah sesuai standar sifat semikonduktor yaitu 10-4 - 109 S.cm (Setiawan dkk, 2007). Penambahan temperatur sintering menjadi $450^{\circ} \mathrm{C}, 500^{\circ} \mathrm{C}, 550^{\circ} \mathrm{C}$ nilai resistivitas masingmasing 32,66 $\Omega . \mathrm{cm}, 48 \Omega . \mathrm{cm}, 371.75 \Omega . \mathrm{cm}$ menunjukan nilai resistivitas mengalami kenaikan setiap penambahan temperatur sintering, kenaikan nilai resistivitas ini disebabkan menguapnya larutan penyusun FTO karena temperatur sintering yang terus bertambah tinggi sehingga pembentukan lapisan film FTO menjadi berkurang kerapatan maupun densitas jumlahnya.

\section{Analisis Transmitansi Kaca FTO}

Transmitansi adalah kemampuan dari suatu material untuk meneruskan intensitas cahaya yang diterima. Intensitas cahaya yang mampu diteruskan oleh kaca FTO dapat digunakan untuk mengetahui nilai transmitansi sehingga dapat diketahui seberapa tinggi tingkat transparan yang dimiliki oleh kaca FTO yang dihasilkan, uji transmitasi kaca FTO menggunakan alat spektrophotometer UV-Vis. Nilai transmitansi yang dihasilkan dipengaruhi oleh temperatur sintering dan ketinggian jarak cerobong pengionisasi dengan berbagai variasi seperti pada Gambar 6.

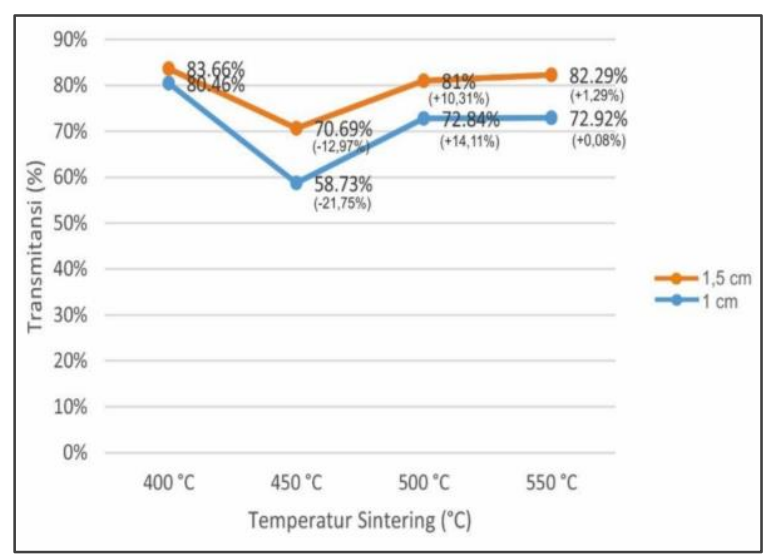

GAMBAR 6. Grafik hubungan transmitansi dengan temperatur sintering

Berdasarkan grafik diatas kaca FTO yang dihasilkan pada temperatur sintering $400^{\circ} \mathrm{C}$ menghasikan nilai transmitansi paling tinggi sebesar $83,66 \%$. Pada setiap penambahan temperatur sintering menjadi $450^{\circ} \mathrm{C}, 500^{\circ} \mathrm{C}$, $550^{\circ} \mathrm{C}$ nilai trasmitansi masing-masing 70,69 $\%, 81 \%$ dan $82,29 \%$ menunjukan nilai transmitansi menurun kemudian naik kembali, faktor yang mempengaruhi penurunan dan kenaikan transmitansi penambahan temperatur sintering karena saat pembentukan lapisan film terhalang kurang konsentrat karena kendala pembentukan material dari fase liquid ke fase 
padat yang berbeda-beda pada setiap penambahan temperatur sintering. Pada fabrikasi kaca FTO temperatur sintering digunakan untuk membuka pori-pori kaca agar kaca dapat terdeposisi FTO namun temperatur sintering yang tinggi juga berpengaruh terhadap permukaan kaca FTO yang terbentuk.

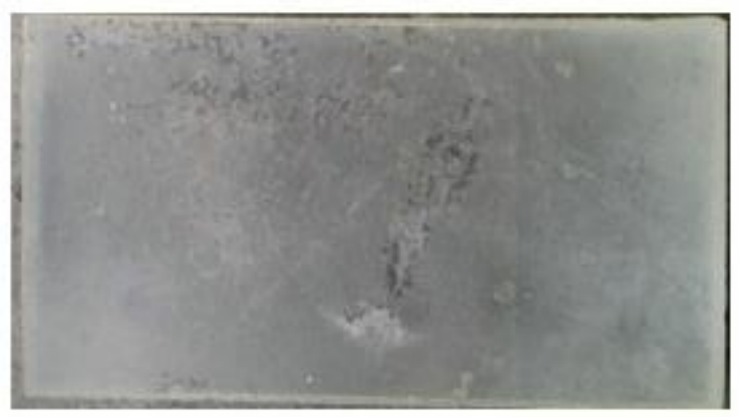

GAMBAR 7. Rusaknya permukaan kaca FTO pada temperatur sintering

Gambar 7, menunjukkan permukaan kaca FTO pada temperatur sintering $550^{\circ} \mathrm{C}$ yang telah mengalami kerusakan akibat temperatur sintering yang tinggi.

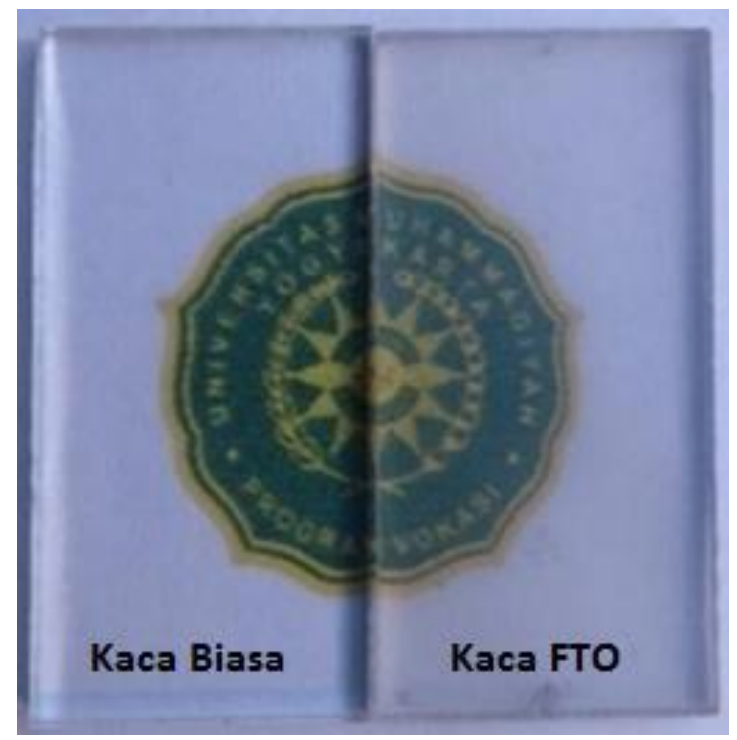

GAMBAR 6. Transparasi kaca biasa dan FTO

Berdasarkan gambar diatas terlihat jelas perbedaan kaca biasa dan kaca FTO, kaca FTO sedikit lebih buram dari kaca biasa karena pada permukaan kaca sudah terdeposisi FTO sehingga menjadi lebih buram. Hasil perpaduan antara nilai resistivitas dan nilai transmitansi dari berbagai variasi temperatur sintering menunjukan kaca FTO yang diperoleh pada temperatur sintering $400^{\circ} \mathrm{C}$ dan ketinggian jarak cerobong pengionisasi $1 \mathrm{~cm}$ merupakan kaca FTO yang terbaik dengan nilai resistivitas 26,72 $\Omega . c m$ dan nilai transmitansi $80,46 \%$.

\section{KESIMPULAN}

Berdasarkan analisa yang telah dilakukan terhadap sifat optik kaca FTO dengan variasi temperatur sintering dan ketinggian jarak cerobong pengionisasi dapat diambil kesimpulan sebagai berikut :

1. Penambahan nilai variasi pada temperatur sintering dan ketinggian jarak cerobong pengionisasi mempengaruhi nilai konduktivitas kaca FTO menjadi menurun. Nilai konduktivitas kaca FTO yang tinggi diperoleh pada temperatur sintering $400^{\circ} \mathrm{C}$ dengan nilai resistivitas sebesar $26,72 \Omega . \mathrm{cm}$.

2. Penambahan nilai variasi pada temperatur sintering mempengaruhi nilai transmitasi kaca FTO menjadi menurun dan penambahan nilai variasi ketinggian jarak cerobong pengionisasi mempengaruhi nilai transmitasi kaca FTO menjadi naik. Nilai transmitansi kaca FTO yang tinggi diperoleh pada temperatur sintering $400^{\circ} \mathrm{C}$ dan ketinggian jarak cerobong pengionisasi 1,5 cm sebesar $83,66 \%$.

\section{DAFTAR PUSTAKA}

Arini, T., Lalasari, L.H., Yuwono, A.H., Firdiyono, F., Andriyah, L. and Subhan, A., 2017. Pengaruh Waktu Deposisi dan Temperatur Substrat Terhadap Pembuatan Kaca Konduktif FTO (Fluorine doped Tin Oxide)[The Influence of Deposition Time and Substrate Temperature in Manufacturing Process of FTO (Fluorine doped Tin Oxide) Conductive Glass. Metalurgi, 32(1), pp.1-8.

Buchori, L., 2004. Buku Ajar Perpindahan Panas Bagian 1. Universitas Diponegoro, Semarang.

Fauziah, E. Astuti dan Fitri Nur Pratiwi. 2013. Pembuatan Gelas Transparan FTO (Fluorine Tin Oxide) Sebagai Bahan Baku Sel Surya, Tugas Akhir Program Studi Diploma III, Teknik Kimia UNS. 
Hao, S., Wu, J., Huang, Y. and Lin, J., 2006. Natural dyes as photosensitizers for dyesensitized solar cell. Solar energy, 80(2), pp.209-214.

Noor Rachmad, D., Arifin, Z., Jaya Saputra, T., Omid, M.A. and Yusuf, M., 2015. Effect of Natural and Synthetic Dyes on the Performance of Dye-Sensitized Solar Cells Based on $\mathrm{ZnO}$ Nanorods Semiconductor. In Applied Mechanics and Materials (Vol. 699, pp. 577-582). Trans Tech Publications Ltd.

Oktaviani, Y., 2014. Sintesis Lapisan Tipis Semikonduktor dengan Bahan Dasar Tembaga $(\mathrm{Cu})$ Menggunakan Chemical Bath Deposition. Jurnal Fisika Unand, $3(1)$.

Prasetya, A.N. and Susanti, D., 2013. Pengaruh Temperatur Kalsinasi pada Kaca FTO yang di-coating $\mathrm{ZnO}$ terhadap Efisiensi DSSC (Dye Sensitized Solar Cell) yang Menggunakan Dye dari Buah Terung Belanda (Solanum betaceum). Jurnal Teknik ITS, 2(2), pp.F378-F383.

Prasetya, A.N. and Susanti, D., 2013. Pengaruh Temperatur Kalsinasi pada Kaca FTO yang di-coating $\mathrm{ZnO}$ terhadap Efisiensi DSSC (Dye Sensitized Solar Cell) yang Menggunakan Dye dari Buah Terung Belanda (Solanum betaceum). Jurnal Teknik ITS, 2(2), pp.F378-F383.

Purba, R.P., 2009. Produksi Etanol dengan Variasi Inokulum dan Kadar Pati Jagung Pada Kultur Sekali Unduh. Skripsi Fakultas Teknobiologi Universitas Atma Jaya, Yogyakarta.

Toifur, M. and Asmiarto, D., 2017, February. Perbaikan Kinerja Probe 4 Titik Melalui Pelapisan Perak dengan Metode Electroplating pada Variasi Waktu Deposisi. In Prosiding The 5th University Research Colloquium (pp. 1280-1286). UAD Yogyakarta.

Widiyandari, H., Purwanto, A., Hidayanto, E. and Diharjo, K., 2012. Fabrikasi Gelas Transparant Konduktif FTO (FlourineDoped Tin Oxide) Dan Aplikasinya Pada Sel Surya Berbasis Dye (DSSC). Prosiding InSINas, pp.88-92.

Widiyastuti, W., Bahriyah, S., Kusdianto, K., Madhania, S. and Winardi, S., 2011, February. Sintesis $\mathrm{ZnO}$ : Al Sebagai Bahan Transparent Conducting Oxide (TCO) dengan Metode Spray Pyrolysis.
In Prosiding Seminar Nasional Teknik Kimia "Kejuangan" 2011.

Yadav, A.A., Masumdar, E.U., Moholkar, A.V., Neumann-Spallart, M., Rajpure, K.Y. and Bhosale, C.H., 2009. Electrical, structural and optical properties of $\mathrm{SnO} 2$ : $F$ thin films: Effect of the substrate temperature. Journal of Alloys and Compounds, 488(1), pp.350-355.

https://adelyadesi.lecture.ub.ac.id,AZG.Spektro fotometri ditulis oleh Adelya Desi pada web Kurniawati diakses17 Maret 2020 